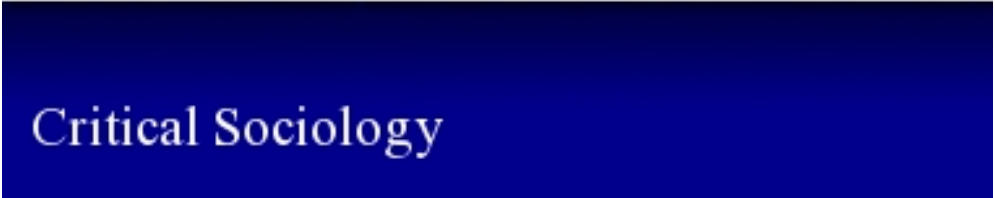

\title{
After the Foxconn Suicides in China: A Roundtable on Labor, the State and Civil Society in Global Electronics
}

\begin{tabular}{|c|c|}
\hline Journal: & Critical Sociology \\
\hline Manuscript ID & CRS-21-0069 \\
\hline Manuscript Type: & Article \\
\hline Keywords: & $\begin{array}{l}\text { Suicide, global electronics production, global value chains, labor rights, } \\
\text { Migrant Workers, student interns, corporate responsibility, public } \\
\text { procurement }\end{array}$ \\
\hline $\begin{array}{l}\text { Please choose from the } \\
\text { following the areas that best } \\
\text { reflect the general topic of } \\
\text { your submission:: }\end{array}$ & Labor, Globalization \\
\hline \multirow[t]{2}{*}{$\begin{array}{r}\text { Please choose from the } \\
\text { following geographical areas } \\
\text { that reflect the area of your } \\
\text { study: }\end{array}$} & East Asia and the Pacific \\
\hline & $\begin{array}{l}\text { We seek to tackle myriad problems of a global production system in } \\
\text { which China is the world's largest producer and exporter of consumer } \\
\text { electronics products. Dying for an iPhone simultaneously addresses the } \\
\text { challenges facing Chinese workers while locating them within the global } \\
\text { economy through an assessment of the relationship between Foxconn } \\
\text { (the largest electronics manufacturer) and Apple (one of the richest } \\
\text { corporations). Eight researchers from Asia, Europe and North America } \\
\text { discuss two main questions: How do tech behemoths and the Chinese } \\
\text { state shape labor relations in transnational manufacturing? What roles } \\
\text { can workers, public sector buyers, non-governmental organizations and } \\
\text { consumers play in holding multinational corporations and states } \\
\text { accountable for human rights violations and assuring the protection of } \\
\text { worker interests? We also reflect on the possibility that national } \\
\text { governments, the electronics industry and civil society groups can } \\
\text { collaborate to contribute to improved labor rights in China and the world. }\end{array}$ \\
\hline
\end{tabular}

\section{SCHOLARONE" Manuscripts}




\title{
After the Foxconn Suicides in China: A Roundtable on Labor, the State and Civil Society in Global Electronics*
}

\author{
Jenny Chan, The Hong Kong Polytechnic University, Hong Kong \\ Greg Distelhorst, University of Toronto, Canada \\ Dimitri Kessler, Economic Rights Institute, Hong Kong \\ Joonkoo Lee, Hanyang University, South Korea \\ Olga Martin-Ortega, University of Greenwich, UK \\ Peter Pawlicki, Electronics Watch, Germany \\ Mark Selden, Cornell University and Columbia University, USA \\ Benjamin Selwyn, University of Sussex, UK
}

\begin{abstract}
We seek to tackle myriad problems of a global production system in which China is the world's largest producer and exporter of consumer electronics products. Dying for an iPhone simultaneously addresses the challenges facing Chinese workers while locating them within the global economy through an assessment of the relationship between Foxconn (the largest electronics manufacturer) and Apple (one of the richest corporations). Eight researchers from Asia, Europe and North America discuss two main questions: How do tech behemoths and the Chinese state shape labor relations in transnational manufacturing? What roles can workers, public sector buyers, non-governmental organizations and consumers play in holding multinational corporations and states accountable for human rights violations and assuring the protection of worker interests? We also reflect on the possibility that national governments, the electronics industry and civil society groups can collaborate to contribute to improved labor rights in China and the world.
\end{abstract}

\section{Keywords}

Suicide, global electronics production, global value chains, labor rights, migrant workers, student interns, corporate responsibility, public procurement, the Chinese state

\section{Introduction}

\section{Jenny Chan and Mark Selden}

In 2010, eighteen workers were known to have attempted suicide at Foxconn Technology Group's facilities in China. Fourteen died and four survived with crippling injuries. Ranging in age from seventeen to twenty-five, all were rural migrants in the prime of youth (Chan et al., 2020: 212). Suicide is experienced as an intensely personal struggle on the part of the individual though it is often embedded in wider tensions in society (Durkheim, 1897; Case and Deaton, 2020; Waters, 2020). As Julietta Hua (2018: 321) argues, capitalism is 'implicated as operating on an uneven distribution of risk' and 'the extraction of worker vitality'. The tragic loss of young

\footnotetext{
* The eight authors have contributed equally to this article
} 
lives reverberated throughout China and internationally, inspiring a global call to guarantee worker rights and prevent more deaths.

Foxconn is Taiwan's as well as China's biggest company. Since 2002, following China's accession to the World Trade Organization, foreign capital including Foxconn has achieved dominance in medium- and high-tech industries, generating over $80 \%$ of the country's export value (Liu and Tsai, 2020: 18). From raw material extraction to processing to final assembly, Foxconn has built a network predicated on vertical integration and flexible coordination across multiple facilities with 24-hour continuous assembly. At present the Taiwanese multinational (Foxconn Technology Group, 2020: 6) commands nearly 40\% of the world market in electronics products. It is the biggest supplier of Apple and a major contractor of Amazon, Microsoft, Intel, Dell, Samsung, Sony and Huawei, among others. It has increased investment in research centers and manufacturing hubs in the Czech Republic, Japan, Vietnam, India, Mexico, Brazil and North America, although these facilities are dwarfed by its facilities in China (Pun et al., 2020). By December 2019, Foxconn had a worldwide workforce of 912,210 employees, with 812,968 based in Greater China (Foxconn Technology Group, 2020: 38). In the wake of consumer movements focused on Nike, Adidas, and other garment and footwear companies, have Foxconn and Apple become more sensitive to anti-sweatshop campaigns staged by civil society actors?

\section{Chinese rural migrants and student interns in the 'Electronics Workshop of the World'}

As Foxconn strives to dominate higher value-added segments of global production, its aspirations align with China's goal to become the world's technological superpower. Nevertheless, it confronts formidable challenges in capturing greater gains from moving up the electronics value chains (Kraemer et al., 2011; Starrs, 2013). Apple-given its control over the commanding heights of hardware, software and design — remains in the driver's seat in setting the terms and conditions for its suppliers. In fiscal year 2009, Apple sold 20,731,000 iPhones, and sales increased by 93\% to 39,989,000 units in fiscal year 2010 (Apple, 2011: 30). With a sudden influx of rush orders from Apple, among other firms, Foxconn workers-including the suicidal workers - were toiling day and night.

The Chinese Labor Contract Law, which came into force in January 2008, raised hopes of strengthened employment security and labor protection. The law guaranteed employees the right to an open-ended labor contract after signing two consecutive fixed-term contracts. However, both state and non-state enterprises frequently circumvent the law by outsourcing labor to cut costs and enhance flexibility (Liu, 2014: Gallagher, 2017; Lee, 2019). Paradoxically, government attempts to promote permanent employment drove increased efforts by employers to use contract and temp labor.

Internships enable management to periodically extend working hours and adapt the workforce to boom-and-bust production cycles of electronics products by laying off interns (Chan et al., 2020). Both suppliers and buyers take advantage of student labor, which is organized by local governments in collusion with employers. Maintaining that student interns are not employeeseven when they perform work identical to that of production workers - Foxconn does not enroll interns in local social security. The open secret is that from day one 'student workers' are placed on the assembly line to do overtime and night-shift work in violation of laws governing 
internships. They are barred from resigning from internships that are devoid of relevant skills training under threat of expulsion from schools.

In the aftermath of the string of Foxconn suicides and labor protests, Apple and other tech giants have sought to minimize financial and reputational risks by shifting orders to lower-wage regions from within and outside China. As of 2015, China's average urban wages surpassed those of Malaysia, among other countries in Asia and the Pacific (ILO, 2016: 2). Coupled with slower economic growth and stronger trade pressure, however, Chinese wage growth among low-skilled workers has decelerated (Rozelle et al., 2020).

\section{Chinese authoritarianism, labor politics and globalization}

Young male and female workers at Foxconn, like their peers elsewhere, aspire to earn a living wage, develop technical skills, enjoy comprehensive welfare benefits, marry, and secure the full range of citizenship rights in the cities they inhabit. Chinese industrialization and urbanization have accelerated in relatively under-developed central and western regions, allowing some of these migrant youth to work closer to home (Yang and Gallagher, 2017; Phelps et al., 2021). However, employees' social insurance funds, especially those of rural migrants, are often lost in job transfers even within the same company. Amid the massive, corporate-led migration, workers and their families experience heightened pressure and resentment of forced moves (Chan et al., 2020: 113-116).

In the absence of effective union organization, some workers exercise their agency by quitting immediately following payday, while others fight collectively for their economic and political rights. In key nodes of production networks, particularly in periods in which sales leaps are expected, labor actions can send important messages to the state, to the employer and to global brands (Chan et al., 2020: 164-170). Worker-led (rather than union-led) strikes and protests at numerous Foxconn sites have been part of a pattern of growing labor insurgency across China (Friedman, 2014; Elfström, 2021). Local officials have acted aggressively to combat disruptions to tight-knit supply chains while helping to mediate settlements in selected cases of worker demands to rectify blatant corporate abuses.

Chinese authorities have responded with both greater responsiveness and greater repression to handle labor unrest (Howell and Pringle, 2019). On the one hand, government- and company-led grievance resolution mechanisms, supplemented with informal channels for addressing worker complaints, have expanded. On the other hand, worker leaders are often dismissed. Worse yet, they risk criminal charges such as 'disturbing public order'. Sensitive news like employee suicides, industrial fires and aluminum-dust explosions are suppressed (Chan et al., 2020: 102103). However, when activists insist on global trade rules that protect worker rights, and consumers and investors hold business interests responsible for the conditions under which iPhones and other products are produced, there is some space for grassroots organizing and for corporate responsibility and consumer campaigns at different levels.

\section{Labor, the state and civil society in global electronics}

In the following, we begin with an overview of the globalization of electronics production in East Asia and the rise of China, with profound implications for workers' struggles and social change (see Lee article). Corporate-led 'development' has brought about highly uneven levels of 
development around the globe with workers striving to break 'global poverty chains' and to fight for decent working conditions (see Selwyn article). We then look into the contested terrain between management and workers at the workplace level. Foxconn - with its massive market power and use of illegal labor practices - has mobilized local states to recruit hundreds of thousands of 'student interns' for business expansion. Apple, among many others, has benefited from 'forced student labor' in its supplier bases. Under mounting criticism, multinational corporations pledge to strengthen corporate responsibility and to engage with the state to create a level playing field. Outcomes remain highly uncertain (see Distelhorst article). Depression in response to coercive labor relations and unstable employment conditions has grown, sometimes leading to employee suicides in and well beyond Foxconn (see Kessler article). To rectify such problems, since 2015, Electronics Watch has collaborated with public sector buyers such as universities to promote a system of responsible procurement (see Pawlicki and Martin-Ortega article). There has been some progress in increasing transparency and worker monitoring in electronics supply chains. In conclusion, we discuss the significance of building workers' power in a cross-class movement and mobilizing national governments to serve working people. We also propose new research projects contributing towards fair labor standards and sustainable electronics.

\section{Workers' Struggle in Electronics Global Value Chains: Persistence and Change}

\section{Joonkoo Lee}

The formation of global value chains (GVCs) has become integral to globalization. GVCs refer to a globalized system of production characterized by geographic dispersion and organizational fragmentation. Participation in GVCs was promoted by international institutions and embraced by developing countries as a viable pathway for economic growth (Gereffi, 2018). This new phase of the global economy, at the same time, generated grave concern about its impact on workers integrated in GVCs. Trade and investment liberalization gave multinational corporations (MNCs) greater flexibility and mobility vis-à-vis workers, and competition for outsourcing orders raised the possibility of the 'race to the bottom' and 'immiserating growth' (Chan, 2003; Kaplinsky et al., 2002). National labor laws and international governance structures were criticized for their ineffectiveness in regulating transnational economic activities in GVCs to protect workers. Private labor standards (e.g., MNCs' codes of conduct) had only limited success in ensuring decent working conditions (Locke, 2013).

The gap in supply-chain labor rights protection was brought to light most dramatically in the case of Apple, Foxconn, and workers in China. Dying for an iPhone painfully traces a wave of Foxconn workers' suicides in China in the early 2010s and its fallout for workers, families and society. The book illuminates how electronics GVCs brought about a labor regime that created multiple hardships for workers while ensuring greater power and value capture for global brands like Apple and key suppliers like Foxconn.

From an historical perspective, the Apple-Foxconn case represents both persistence and change in the structure of the global electronics industry and its impact on labor. The rise of foreign direct investment from the Global North in search of low-cost labor was a key driver in the 
expansion of electronics manufacturing in the Global South since the 1960s. In East Asia, entry into the global circuit of electronics production was initially driven by western MNCs and spurred since the 1980s by the regional expansion of firms from Japan and newly industrializing economies, notably Taiwan and South Korea (Borrus et al., 2000). This export-oriented industrialization, often promoted by authoritarian governments, tended to prioritize export growth at the cost of worker rights. It ignited deep discontent among workers, many of them young rural migrants, leading to labor unrest (Koo, 2001). MNCs, in response, relocated production to other lower wage labor locations, expanding both industrial jobs and the terrain of labor unrest in Asia (McKay, 2006). Chinese workers' struggle, thus, illustrates the recent geographic reconfiguration of electronics GVCs and enduring labor problems.

At the same time, the Apple-Foxconn case casts light on a changing face of the industry. Global lead firms like Apple tightly control higher value-added segments of the chain, from research and development (R\&D) to branding, as well as determining what products will be made, where, when and by whom. Manufacturing is largely outsourced to contract suppliers like Foxconn that provide technological support and logistics to multiple global brands. While both manufacturing and brand nodes of the chains are concentrated in a handful of MNCs, value distribution is dominated by brand buyers, with a slim margin left to contract suppliers and assemblers.

This organizational separation through outsourcing and the uneven power distribution in GVCs have significant repercussions for manufacturing workers in China and other countries. Global lead firms and transnational contract manufacturers have become more mobile and tightly connected via GVCs, but workers' cross-country mobility is relatively limited. As documented throughout the book, workers' grievances are rarely addressed anywhere in the value chain. Production plans and working conditions at the supplier factory are strongly influenced by the lead firm's business strategies (Locke and Samel, 2018). A notable example is the considerable seasonal fluctuation of production volumes in electronics, partly attributable to Apple's strategy of blanketing the market with new product models in a short period of time, especially during the Christmas season (Chan et al., 2020). Emulated by its competitors, this blockbuster model of sales and marketing heavily constrains the way suppliers manage production and the workforce, resulting in widespread use of casual workers including student interns, excessive and often illegal overtime, and the cycle of massive recruitment and layoffs.

This does not mean that no improvement has occurred. Rather, workers' struggles in China and civil society actions worldwide brought about significant changes in the global electronics industry and the treatment of workers. Activists (SACOM, 2011) played a key role in exposing the harsh reality of labor behind cool gadgets, fancy TV commercials, and highly choreographed product launching events that have become an annual ritual of the industry. In fact, labor protests at Foxconn, Honda, and Yue Yuen (a 'Foxconn' of footwear), to name only a few, provided an awakening for many young migrant workers. As in apparel and sportswear a few decades earlier, growing public awareness and criticism, spurred by activist campaigns, media reports and social media posts, placed mounting pressure on global electronics brands to address social and environmental concerns in their supply chains.

Corporate codes of conduct and factory audits have become institutionalized, although their effectiveness is still debated. In the face of workers' resistance, MNCs have also moved or 
expanded their operations to low wage areas of inland China or to Vietnam and India. The government took greater notice of labor unrest and made some effort to improve labor relations while tightening social control. These adaptive measures implemented by both MNCs and governments might explain the persistence of 'Foxconn type' labor relations and workers' limited gains despite their resistance (Lüthje and Butollo, 2017).

The Apple-Foxconn case and ensuing developments raise important questions for future labor activism. China is the latest episode of 'economic upgrading without social upgrading', where firms, including but not limited to Foxconn, have improved their positions in GVCs in the absence of significant improvement in labor standards (Barrientos et al., 2011). Looking forward, the global electronics industry faces great uncertainty. The U.S.-China war over trade and technology has unsettled one of the most important linkages in electronics GVCs, raising the possibility that GVCs would bifurcate into one for the U.S. and its allies and another for China and associated countries. MNCs are being pressured to leave China for Vietnam, India, or other countries, or (less likely) to bring factories back home. More recently, the COVID-19 pandemic has brought about enormous disruptions, but it is too soon to tell whether GVCs will shrink. MNCs' strategic actions including automation and digital transformation, as history has shown, will likely contribute to the expansion of GVCs (Gereffi et al., 2021). Meanwhile, electronics and information technology have become more central in capital accumulation, or the so-called 'Fourth Industrial Revolution'. The critical question is what opportunities and challenges the upcoming round of GVC reconfigurations pose for workers and labor movements worldwide.

\section{China, Tech-Capital and Poverty Wage Labor Regimes}

\section{Benjamin Selwyn}

The 2020 World Development Report asserts that global value chains 'boost incomes, create better jobs, and reduce poverty' (World Bank, 2020: 3). It reflects a general mainstream consensus that GVCs generate novel opportunities for development for poor regions (Selwyn and Leyden, 2021). As the new 'workshop of the world', China has underpinned the expansion of GVC production and trade. Students of development will be familiar with the claim that China's participation in GVCs has drawn hundreds of millions out of poverty, thereby contributing significantly to achieving the first Sustainable Development Goal—of a world without poverty by 2030 .

Such perspectives promote a triple-win conception of development: What is good for transnational corporations (higher profits through outsourcing) is good for the workers they employ and their suppliers (who get better jobs and higher wages), and for consumers (who can purchase cheaper products). In this way, they draw upon and seek to fortify one of the classic tropes of liberal development theory-Adam Smith's assertion that an expanding division of labor raises productivity, lowers prices, and enhances firms' profits.

In this ideologically charged context, Dying for an iPhone represents a rare, and important, type of scholarship. Based on a decade of intense, often undercover, research, Chan and her coauthors provide a vivid description and analysis of workers' lived experiences of laboring for Foxconn- 
China's biggest private-sector employer by total number of employees and one of the firms that defines globalization. The book generates the basis for a critique of the claim that China's growth linked to the global trade system is a main driver to alleviating poverty. I will draw upon the empirical detail to contribute to such a critique and to show how, on the contrary, Foxconn's and thus also China's rise is based on the generation of novel forms of poverty wage labor.

The problem with the 'China-is-reducing-worldwide-poverty' narrative is that it all too frequently relies on the World Bank's International Poverty Line (IPL) of \$1.90 a day. The IPL reflects a level of consumption that the Bank considers to be the dividing line between extreme poverty (below the line) and poverty (above the line). But as Philip Alston, the UN's special rapporteur on extreme poverty and human rights argued, this poverty line is 'scandalously unambitious' (quoted in The Guardian, Beaumont, 2020). As I show, the IPL does not cover the costs of adequate food, clothing, shelter or other basic human needs (Selwyn, 2017). Moreover, it is unconcerned with the form of work undertaken by laborers to secure their livelihood. In this way, it detaches the association of indecent work from widespread global poverty. Rather, a focus on the labor process and labor regime - the way work is organized and labor recruited and mobilized - enables us to trace the links between indecent work and poverty wages in GVCs.

Employing a more humane poverty line in place of the World Bank's $\$ 1.90$ a day metric, we see the world, China's rise, and employment in Foxconn, in a different light. The Clean Clothes Campaign (a global network dedicated to improving working conditions and empowering workers in the garment and sportswear industries) and Asia Floor Wage Alliance (an Asian labor-led global labor and social alliance) provide alternative guidelines for assessing poverty. They note that a living wage should be earned in a standard working week of no more than 48 hours and allow a worker to be able to buy food and other necessities for herself and her family, pay the rent, pay for healthcare and education, and have modest savings. Absent these conditions, work is indecent and based upon poverty wages.

Dying for an iPhone has two core focal points. First, it details Foxconn's position in the global high-tech chain, principally its relations with Apple for whom it produces and assembles iPhones, iPads, iPods and other leading-edge consumer goods. Apple captures the lion's share of the value embodied in the iPhone, with direct and severe, consequences for Foxconn's workers. Second, it analyzes how these inter-firm relations impact upon capital-labor relations within Foxconn, with a particular focus on the ways in which it deploys its labor force to sustain its position as key supplier to the tech-giant.

As of May 2010, amid the spate of worker suicides, Foxconn had been paying its assembly line workers at statutory minimum wage levels in China. In Shenzhen city on the northern border of Hong Kong, for example, the basic wage was 900 yuan or approximately $\$ 130$ a month (with legal reference to an 8-hour workday and 21.75 working days a month). Referring to a 31-day calendar month, then, it was $\$ 4.19$ a day. While Foxconn workers earn significantly above the IPL, they do so under conditions of 'compulsory overtime, lack of fundamental health and safety precautions, abusive treatment of teenage student interns, and managerial repression of workers' attempts to press demands for securing rights guaranteed by employment contracts and national labor laws' (Chan et al., 2020: xiv). 
Interviews show that base wages at Foxconn are 'so low' that overtime is in effect compulsory. As one worker testifies 'I woke up at 6:30 a.m., attended a morning meeting at 7:20, started work at 7:40, went to lunch at 11:00, and then usually skipped the evening meal to work overtime until 7:40 p.m.' (Chan et al., 2020: 6). While Chinese law stipulates a normal work week of 40 hours and limits overtime to 36 hours a month, workers are documented as laboring for up to 120 additional hours a month — with some only getting one day off a month in busy seasons.

Workers accommodated in Foxconn's dormitory system have to pay rents, which are taken directly out of their wages. Conditions are dire and are designed to demoralize and divide workers:

a shared dormitory room housing eight to twenty-four workers in double-decker bunk beds. Quarrels over toilet and shower use, noise, and security problems in the dormitories are frequent and demoralizing.... Husbands and wives do not share a private dormitory room with their spouse, but are housed separately in male and female dormitories (Chan et al., 2020: 106).

Factory dormitories house a massive migrant labor force. The workplace and living space are compressed to facilitate high-speed, round-the-clock production.

Scientific management, initiated by Frederick Winslow Taylor in the early $20^{\text {th }}$ century was designed so that 'all possible brain work should be removed from the shop and centred in the planning or lay-out department' (Taylor, 1903: 1390). Foxconn's engineers 'study the entire manufacturing process in minute detail...the posture of workers sitting or standing is monitored no less rigorously than the work itself' (Chan et al., 2020: 59). One worker describes their job as:

Take a motherboard from the line, scan the logo, put it in an anti-static bag, stick on a label, and place it on the line. Each of these tasks takes two seconds. Every ten seconds I finish five tasks (Chan et al., 2020: 60).

Following Harry Braverman (1974) the authors note how labor process management is not simply a technical issue but a key moment of class conflict. While Foxconn uses engineers to increase the speed of the labor process, workers resist by taking individual and collective actions. Yet slowing down work is a well-known tactic to management. In response, engineers revamped the standard operations manual. A worker explains how:

Now we must use both hands at work to increase efficiency and productivity. Not a hand is left idle for a moment...for example, I hold an electric screwdriver with my right hand, and fix the screws with my left hand. Then, I pick up another printed circuit board. I screw the screws without a break (Chan et al., 2020: 60).

The intensity with which Taylorist techniques are deployed at Foxconn physically harms workers - another indication of indecent work.

Foxconn's practices are facilitated by the broader labor regime. On-site dormitories mean that workers are ever available for last-minute production drives. Deliberately low state-mandated 
minimum wages are designed to extract vast overtime hours from workers. A state-controlled national trade union functions to supress workers' collective actions. And above-all, the household registration system divides the national workforce into rural migrants and urban dwellers, denying the former the rights enjoyed by the latter and increasing their vulnerability to the payment of below subsistence wages.

Dying for an iPhone has done an impressive job describing and explaining the labor process at Foxconn, the wider labor regime within which it is reproduced, and the ways in which poverty wages underpin this form of GVC-based development. But how representative is the Foxconn 'Chinese model'? Foxconn is the largest player in electronics assembly and manufacturing. Dic Lo (2020), considering the contributions of state-owned and domestic private enterprises as well, cautions against characterizing the 'Foxconn model' as typifying China's development. He notes that between 2000 and 2017 real urban wages and the real wage for migrant workers 'increased on average by 10.7\% and 9.7\%, respectively, per annum' (Lo, 2020: 862). Facing competition, Foxconn likewise raised wages to recruit young workers while slashing subsidies and bonuses to offset the costs.

From the early 2000s onwards, China has increased statutory minimum wages to boost domestic consumption. If we adopt the World Bank's approach, then the Foxconn model is probably no bad thing. Chinese rural migrants have found paid urban jobs. If, on the other hand, we use a more humane conception of poverty, based on the Clean Clothes Campaign's notion of a living wage, we see something very different. Foxconn (and large sections of China's economy and society) have institutionalized poverty wages.

The basic wages paid by firms like Foxconn are insufficient to provide workers and their family with a dignified existence. The labor process (intense Taylorism) and the labor regime (dormitory systems, health-damaging overtime, and institutionally segmented labor forces) represent a core component of China's comparative advantage as a GVC supplier region. Extreme hard work and health-threatening overtime are the basis of this form of economic development (Selwyn, 2019).

Mainstream GVC theory asserts that the path to prosperity for supplier regions is through upgrading. But as Dying for an iPhone shows, China's GVC upgrading trajectory has been constructed upon a poverty wage labor regime. The book finishes with an account of strikes and protests by Foxconn workers. In my view, such struggles by a core section of the world's working class could contribute to further and more significant ameliorations, and perhaps even a decisive challenge to the state's poverty wage labor regime premised on the deprivation of workers' rights to free association and of citizenship.

\section{Control, Coercion, and Corporate Responsibility in Dying for an iPhone}

\section{Greg Distelhorst}

Dying for an iPhone documents the manufacture of novel and technologically advanced consumer products, but the human stories it contains are familiar and very old. The voices of 
Chinese workers therein echo workers more than a hundred years earlier experiencing loss of control over their working lives. Yet the traditional gateways to change - through worker organization and electoral politics — remain barricaded in contemporary China.

Acknowledging the limits imposed by politics, researchers have investigated the extent to which market actors can improve worker rights and working conditions in global supply chains (Locke, 2013). Decades of activist campaigns pushed major corporations to adopt private programs to monitor and manage the employment practices of their suppliers (Esbenshade, 2004; Bartley, 2007). These programs effectively place multinational corporations in the roles of labor regulators, with a range of activities intended to enforce labor standards in their supplier factories including defining codes of conduct, monitoring for compliance, and transferring new management capabilities (Distelhorst, 2020).

Dying for an iPhone takes a hard look at what is actually happening inside factories covered by the supply chain responsibility programs of one of the world's most admired corporations: Apple Inc. In doing so, it prompts readers to ask what could be done differently. However, the book also places these contemporary challenges - most supply chain responsibility programs began in the $21^{\text {st }}$ century - in historical context. The voices of these workers exhibit remarkable continuity with previous generations of workers trying to carve out autonomy, voice, and control over their work lives. As one Foxconn employee puts it:

Foxconn values its engineers, but they are our enemies; we hate them... When industrial engineers come around with their stopwatches, we intentionally slow our work pace...the faster I work, the higher the production quotas, so my co-workers and I slow the pace (Chan et al., 2020: 60).

At the dawn of the last century, workers in a New England military manufacturer offered similar testimony despite laboring under radically different conditions. They were employees of the U.S. government, with greater job stability, shorter hours, and superior benefits compared to private employers of the day. Yet when an early management consultant sought to monitor, measure, and reduce their autonomy in the workplace, they reacted similarly:

The very unsatisfactory conditions which have prevailed in the foundry among the molders for the past week or more reached an acute stage this afternoon when a man was seen to use a stopwatch on one of the molders...It is humiliating to us, who have always tried to give to the Government the best that was in us (Aitken, 1985: 150).

Over one hundred years separate this letter from the publication of Dying for an iPhone, yet both the technology of control - a stopwatch - and the human experience, are unchanged. Despite the relative novelty of supply chain corporate social responsibility (CSR) in global electronics, the abuses and conflicts that it seeks to address are almost as old as industrial manufacturing itself.

Historical parallels between these disparate groups of workers extend to the celebrity leaders whose ideas about workers come to dominate these organizations. Foxconn CEO Terry Gou infamously invited a zookeeper to lecture senior managers on managing animals, explaining 
'[Foxconn] has a workforce of over one million worldwide and as human beings are also animals, to manage one million animals gives me a headache' (Chan et al., 2020: 57). Frederick Winslow Taylor, proselytizer of the new management techniques being imposed on the New England arsenal workers, similarly likened humans engaged in manufacturing to animals. He wrote, 'One of the very first requirements for a man who is fit to handle pig iron as a regular occupation is that he shall be so stupid and so phlegmatic that he more nearly resembles in his mental make-up the ox than any other type' (Taylor, 1911: 59).

The experiences of workplace control and dehumanizing rhetoric documented in Dying for an iPhone are not unique to Foxconn, to global supply chains, or even to authoritarian political regimes. They are common themes in the history of working people. The young rural migrant employees and interns at Foxconn, many of whom were having their first experiences with industrial manufacturing, are only the most recent to share this experience across cultures and generations.

The organization and collective action of working people - manifested in trade unions, protest, and labor-aligned political parties - and paired with economic growth, have allowed many jobs to become more humane over the past century. Yet the hostility of China's current government to autonomous organizations of workers, not to mention political accountability at the ballot box, offers little hope for a labor movement in China absent radical and unexpected change.

With these barriers in place, what are some pathways to improvement? One plausible measure would be to rein in the abuse of internship programs. As documented in Dying for an iPhone, many internships violate Chinese law, which requires that students receive training in their field of study and prohibits overtime work. The book emphasizes the impact of pseudo-internships on aspiring students, but reliance on coerced labor also has consequences for Foxconn's huge population of ordinary employees.

The dismal workplace characterized by the rapid execution of rote tasks, intense supervisory control, and low pay is a common model of employment in electronics assembly. It relies in part on low levels of specialized skill among operators, creating a large pool of low-wage employees and minimal cost of replacing them. While touring an electronics assembler (not Foxconn) in mainland China roughly a decade ago, I asked how much training an employee assembling computer enclosures received. The manager explained, 'No training. You could join the production line yourself right now.' He was exaggerating, but it illustrated the perspective of managers that literally anyone could do these jobs, and that an experienced employee was nearly interchangeable with a new one.

China's economic growth over the last forty years tends to strain these low-wage, lowproductivity models of manufacturing. As industrial labor grows scarcer relative to the size of the manufacturing sector, employers should compete for workers by raising their wages. Rising costs of labor in turn reward employers for designing jobs in which employees become more productive through the increased application of skill and technology. Some buyers have sought to accelerate transitions in their suppliers' employment models through capability-building programs (Distelhorst et al., 2017; Lollo and O’Rourke, 2020; Boudreau, 2020). 
On the other hand, guaranteeing a reserve workforce of low-wage, coerced workers - such as student interns obligated to work for their educational credentials - dampens this effect. When intern credits are required for obtaining a degree, local governments can extract the labor of students seeking to invest in skills, conscripting them into manufacturing employment to meet the production needs of exporters like Foxconn. The students eventually receive an educational credential, but such 'internships', far from providing educational value, acclimate students to an oppressive disciplinary environment.

Foxconn's reliance on teenage students is staggering. The book reports 150,000 interns in summer 2010, and introduces readers to construction students polishing casings, petro-chemists affixing labels to boxes, and fashion students required to tighten screws (Chan et al., 2020: 7577). For nearly a decade groups like Students and Scholars Against Corporate Misbehavior (SACOM), China Labour Bulletin, and China Labor Watch have revealed misuse of student interns in electronics supply chains.

If China's government wished to accelerate a transition to higher-productivity, higher-pay industrial manufacturing, one step would be disrupting these government-enabled pipelines of teenage students into low-skill and temporary manufacturing roles. This would protect the right of ordinary workers to sell their labor in a well-ordered market, rather than competing against coerced laborers trying to complete their education. Despite updated national regulations on internship programs in 2016, investigators recently found yet more 'interns' working overnight shifts at Foxconn to complete orders for Amazon (Chan et al., 2020: 184).

Reforming intern labor would admittedly do little to generate the foundations of collective power through trade unions primarily accountable to their worker constituents. Those remain out of reach for a governing party that remains deeply hostile to workers organizing and advocating for themselves (Fu, 2018).

Returning to supply chain responsibility programs, global buyers like Apple and its competitors have both an ethical duty to the people who manufacture their products and a range of constructive roles they can play in these workplaces. They can monitor the experiences of their supply chain workers, implement programs to address failures, and avoid purchasing behavior that incentivizes the very practices their code of supplier conduct prohibits. It would be welcome, for example, to see buyers tighten their monitoring of student interns. However, the last two decades of research on market-based interventions to enforce labor standards shows that even model programs struggle to overcome local institutional constraints and labor market dynamics (Distelhorst et al., 2015; Toffel et al., 2015; Bartley, 2018).

Still, the role of buyers has expanded through the last decade of research and activism reflected in Dying for an iPhone. In 2010, Apple CEO Steve Jobs defended the Foxconn site of multiple worker suicides as, 'a pretty nice factory' (Chan et al., 2020: 50). In 2020, Apple's Supplier Responsibility report ran over one hundred pages ranging from claims of progress on basic labor standards for student internships and debt-bonded labor. Reported activities included following up with over 30,000 participants in audits to check for retaliation, and workplace surveys of over 40,000 workers (Apple, 2021). 
Even if these corporate programs will not eliminate abuses of worker rights in global supply chains, activism has dramatically expanded the scope of impacts for which global brands like Apple accept at least nominal responsibility. None of this would have happened without the work of pressure groups and journalists to highlight these issues in a high-tech industry and especially in one of the world's most valuable, profitable, and admired corporations. Dying for an iPhone is a call to arms, but it is also the capstone of a successful decade of pressure to redraw the boundaries of corporate responsibility in the global electronics industry.

\section{Responses to Employee Suicides in the Chinese Electronics Sector}

\section{Dimitri Kessler}

When Foxconn experienced the surge of employee suicides in 2010, the firm insisted the suicides were not linked to employment conditions (Chan et al., 2020). They stressed that the suicides, in the context of Foxconn's one million employees, fell below the norm of suicides per 100,000 Chinese citizens.

One problem with this logic is the presumption that the link between suicide and employment is not embedded within the 'norm' of suicides. The persistence of drunk driving collisions does not justify forgiving drunk drivers for negligence. We strive to hold drunk drivers responsible and reduce the number of people driving drunk. Yet some find the question more difficult, should employers ever be considered negligent in events ending with suicide?

Suicide is self-injury, and some suggest this justifies excluding suicide from restitution for workers who die due to their work. Employers commonly believe responsibility should lie exclusively with employees who end their lives, and employers like Foxconn's CEO, Terry Gou, like to highlight the connection between suicide and victims' lives off the job (Kan, 2014). Even when experiences on the job were the trigger, suicide frequently follows from multiple conditions, so it is not productive to try to pinpoint only one 'problem' behind someone's suicide (Phillips et al., 1999).

Still, surveys of over 5,500 employees from 44 electronics suppliers employing close to 110,000 Chinese confidently link the incidence of suicide to depression in the wider workforce (ERI and EW, 2018). Nine of eleven reported suicides occurred in suppliers where $10 \%$ or more of surveyed employees expressed signs of depression. This concurrence of suicide with workforce depression should doom efforts to reduce suicides to the dysfunction of lone employees. Even if the decision to end one's life is extreme, suicide is connected to influences more widely felt in the environment. Why do some enterprises see more employees feeling depressed and ending their lives? Is there something to distinguish these firms from others where fewer employees feel depressed and resort to suicide?

I theorize two cycles of influence through which employment conditions heighten the risk of suicide. In the cycle of coercion, employers ignore signs of employee stress when setting work norms and use punitive discipline to police production requirements that employees find excessive. Supervisors' shouting and other, less forgiving methods to drive productivity 
contribute to tensions and conflict. Some employees succumb to feelings of helplessness. Others seek retribution 'in the street'. Tensions build, and fistfights, even murders, occur not only between supervisors and employees but between peers stressed by disputes over work responsibilities or benefits. This environment propels employees' depression and pushes some to the brink of suicide. Quantitative analysis strongly supports the core contentions of this theory that productivity requirements that employees consider excessive contribute to hostility, that tensions with supervisors contribute to employee depression and that the blend of hostility, depression and subjective perceptions of tiredness, intensified by employers refusing to give employees time off, heighten the likelihood of suicide (ERI and EW, 2018).

In the second cycle of influence, employers prioritize flexibility. They adapt to poor employee retention, not by improving the conditions which drive employees to resign, but by restructuring incentives to recruit new hires on short notice when needed. This recruitment model contributes to conflicting incentives for employers and employees. Whenever employers need people on production lines more urgently, they offer higher incomes and bonuses to get people through the door more quickly. But the cost of these incentives drives employers to tricks and schemes to reduce their costs, limit who receives better benefits and for how long. The result is the use of deception in recruitment offers designed to hide how employers cut corners, workers working side by side for sometimes wildly different benefits determined by coincidence, not merit, and employers' preference for the use of footloose recruiters better positioned to sidestep responsibility when the employer decides they no longer need the new recruits. This cycle of influence contributes to disputes over broken promises, sometimes the outright theft of recruitment bonuses, the erosion of employees' confidence that their effort and skill will be recognized and short-term employment. The effects of short-term employment extend more visibly to employees' lives off the job by undermining the conditions needed for trust, friendship and family. We believe this contributes to the incidence of suicides of employees distressed by dating and marriage difficulties (ERI and EW, 2018).

Though more evidence is needed to verify this second cycle, studies confirm conditions including long hours (Kim et al., 2019) and flexible employment (Täht and Mills, 2016) heighten the likelihood of divorce. So, employers' instinct to highlight employees' lives off the job is far from sufficient to disprove the effects of employment on suicide. And when employers infringe on workers' rights in the pursuit of self-interest through methods including forced overtime, coercion and corruption to force students to complete internships and the use of deceit and withheld income to trick employees to consent to short term employment, they should be held responsible for the consequences of their choices.

The electronics sector is not sitting idly by following publicity of Chinese employee suicides. My interviews with suppliers with histories of multiple suicides suggest Apple did not limit suicide prevention efforts to Foxconn. More obviously, suppliers use 'suicide nets' and lock windows to deter employees from jumping from heights. Some observers worry that this intervention ignores the deeper issues driving suicide and might even intensify restrictions on employees. But in the Chinese context, where suicide is frequently linked to impulsiveness and not illness, these modest steps likely prevent some loss of life by hindering the short-lived, destructive impulses of employees in distress (Lin and Zhang, 2017). Less well studied, 
however, is the possibility that nets and locked windows trigger thoughts of suicide by reminding employees of the expected risk of new suicides.

There is evidence that some employers screen employees or job seekers for 'eccentric moods' to remove or prevent them from entering the workforce. This highlights how employers might implement prejudiced policies against people suffering mood disorders, promoting cycles reinforcing depression and unemployment (Chen et al., 2012). Other suppliers support counseling hotlines or other volunteer efforts to identify employees in need. Stories of successful interventions suggest that some of these systems help. But in my interviews, even experts involved in their design doubt how effectively these services refer employees to counseling they need. Some suppliers including but not limited to Foxconn invest in support for employees' lives off the job, offering employees fitness equipment, film screenings and other leisure options. The norm of forced excessive overtime still seriously limits the time employees might enjoy these perks.

The industry's response to suicide is evolving. When presented with recent studies of suicide, the Responsible Business Alliance, an alliance of electronics firms seeking to unify code of conduct norms committed to mobilize their membership to conduct 'comprehensive' surveys of one million workers' well-being (RBA, 2018), even trying to use the studies to convince their membership to invest collectively in suicide prevention.

These efforts show some willingness to intervene positively, but we need evidence of how the industry executes their public promises before judging the merits of their efforts. News reports and testimonies still suggest the industry depends on convenient, sometimes cosmetic efforts to fight recognition of deeper issues. To resist responsibility and the specter of government enforced requirements, employers commonly offer restitution to suicide survivors or invest in suicide prevention on the condition that it is considered 'good will'. Most of the industry denies links between suicide and employment, couching themselves in sometimes thinly veiled 'science' even while they exclude dissenting voices and dismiss or censor evidence which conflicts with their self-interested conclusions. The industry rejects more open reporting which could support genuinely independent review of suicide trends. And all too consistently, they do not curb the infringements of workers' rights considered triggering events by close observers or the shocking conduct survivors sometimes endure, including obstruction, deceit, violence and even imprisonment, when employers mobilize to defend themselves from expensive requests for restitution.

The industry is not the only one responding to suicides. The spike in Foxconn suicides in 2010 likely grew in intensity due to the clustering effect which sometimes occurs when publicity triggers some in crisis to mimic others' suicide (Phillips, 1974). This is likely why fourteen out of the eighteen known suicides of Foxconn employees in 2010 occurred in the firm's Shenzhen workforce of 500,000, while only four suicides occurred in the firm's other Chinese sites employing close to 500,000 .

Figure 1 and Table 1 below show 458 suicides of Chinese electronics employees from 2003 to 2020 referenced by online sources. In yellow, we see the Foxconn suicides; in white, suicides which occurred in other electronics firms in the region. The solid lines represent the number of 
incidents where employees sought to end their lives without voicing other objectives. The dotted lines show the number of suicides if we include protests where employees showed some intent to suicide but did so with the end objective of seeking resolution to some dispute. These sources do not fully represent the incidence of suicides in Chinese electronics, but they underline evolution in the reporting and perceptions of suicide. Whether the Foxconn cluster and the publicity surrounding it mirrored or elicited the rise in reported suicides in 2010 , there is no doubt suicides get reported more widely in the electronics sector since then, even if these reports often go unnoticed.

\section{[Figure 1 about here]}

\section{[Table 1 about here]}

The evolution of workers' perceptions of suicide is not limited to employees with thoughts of suicide. Workers sometimes joke of the usefulness of 'suicide' to resolve employment disputes. Though most such protests end without injuries, employees use suicide 'shows' to pressure employers to settle disputes. Noteworthy too, the number of protests where electronics employees climbed to the roof shouting their intent to jump spiked to 20 in 2015 before declining precipitously.

It is difficult to confirm why protests referencing suicide spiked in 2015. The growth of this spike first emerged in 2010, and it seems possible workers were inspired by the publicity of the Foxconn suicides and the perception this pressured Foxconn to improve employment conditions. Lest industry or government cite this phenomenon to justify censorship and resist offers of restitution to suicide survivors - in the vein of 'publicity and restitution only incentivize more suicide' - it is worth stressing again: protests by electronics employees using 'suicide' to pressure employers to resolve disputes seldom end in loss of life, even if some protests were possibly inspired by publicity. Employees fighting, often collectively, for perceived entitlements tend to exhibit tendencies quite distinct from those common to the suicides of hopeless employees without objectives beyond their suicide.

Censorship, police pressure and other forces likely reduced the reporting of suicide protests since 2015, resolving neither the issues driving suicides nor employment disputes. So when the delivery driver in Alibaba's service network set himself on fire in 2021, he set unsettling precedent (Yang and McMorrow, 2021). He combined the lonely distress and will to injure himself common of completed suicides with the desire for public protest which, previously, seemed limited to workers collectively fighting for their future. The incident should remind us that the issues driving employees to suicide might evolve for the worse if the industry does not open itself to genuinely independent oversight and work with experts, government and civil society to develop effective remedies.

\section{Verification, Workers' Voice and Public Procurement-Pathways to Sustainable Improvement}

Peter Pawlicki and Olga Martin-Ortega 
The electronics industry has unresolved human rights and labor rights issues in its supply chains. Dying for an iPhone shows how an entire production sphere can be riddled with grave violations of worker rights in the factories, and environmental pollution and health hazards endangering local communities. Over decades scholars and civil society organizations have regularly documented and analyzed the problems at hand and their systemic drivers.

The Responsible Business Alliance, formerly the Electronic Industry Citizenship Coalition, is the electronics industry's association focusing on sustainability. The corporate members have pooled resources to audit electronics supply chains for more than a decade. However, violations of human and labor rights still are legion. These include abuses which may lead to forced labor and seem pervasive in global supply chains of the electronics industry (Martin-Ortega et al., 2015; EW, 2020a). In fact, the industry's corporate social responsibility (CSR) reports reveal that compliance with the industry's own minimal standards have not been achieved.

Worker representatives and civil society organizations have argued that social audits, certifications, and other industry-led governance measures for human rights do not lead to substantial improvements for workers. Increasingly, data from long-term studies supports this analysis (Outhwaite and Martin-Ortega, 2019). Corporate-funded social audits are ineffective for detecting, reporting or correcting labor problems in supply chains. The top-down approach is based on 'corporate goodwill' that omits the perspective of workers and communities, while often ignoring purchasing practices and locating the responsibility on the factory level and keeping audit reports and corrective action plans secret and thus unverifiable (LeBaron and Lister, 2016; MSI Integrity, 2020: Nelson et al., 2020; Clean Clothes Campaign, 2019).

As long as affected workers and communities do not gain the required voice in monitoring, reporting, remediation and prevention, meaningful improvements will not occur.

Public sector procurement provides one opportunity to go beyond corporate goodwill. Using their purchasing power, public buyers can facilitate supply chain governance based on enforceable contract conditions, worker-driven monitoring and long-term engagement with brands and suppliers (Martin-Ortega, 2018; Claeson, 2019). Most public procurement legal regimes allow the inclusion of social, environmental and innovative criteria in tenders. Accordingly, public buyers have made efforts to verify the criteria they set for the products they buy and learn about the production processes and working conditions of these products.

Verifying social criteria is, however, challenging. Relying solely on certifications, public buyers tend to fall back on the traditional system of corporate audits without taking a more pro-active role to drive significant improvement.

Electronics Watch fosters commitment from public buyers globally. In 2015, it incorporated under Dutch law as a not-for-profit, non-governmental organization. It strives to develop an integrated system of monitoring, verification, and industry engagement to enhance the collective power of public buyers to strengthen labor, social and environmental standards of global electronics supply chains. At its heart is a network of local civil society organizations whose 
experts in labor and human rights lead worker-driven monitoring in factories that are linked to the supply chains of the public buyers affiliated with Electronics Watch.

As of March 2021, 332 public organizations from Europe and Australia have affiliated with Electronics Watch. They include regional governments, universities, city councils, hospitals, purchasing consortia and a public service trade union. During the tender process, certifications for specific standards can be used as selection or award criteria. Conditions included in the signed contract establish and structure rules of engagement for monitoring and remediation during contract management.

Reports based on in-depth interviews and long-term research by monitoring partners inform public buyer affiliates. Electronics Watch shares these reports with manufacturers and brands linked to the supplier factory to assure improvements at the factory and industry levels. Electronics Watch affiliates have established contract conditions that oblige their direct suppliers to follow-up on reports and cooperate with Electronics Watch in improvement processes. With contract periods between two- and five-years, public buyers can gain a better understanding of the situation at the factory and the wider supply chains.

Worker-driven monitoring has proven successful in the context of public procurement. Electronics Watch uses a verification mechanism that encourages workers' participation to provide affiliated public buyers with detailed and timely information about the human rights situation in their supply chains. Public buyers have used the information to secure improvements of the human rights situation. For example, in 2016 Electronics Watch documented problems for migrant and subcontract workers at Foxconn in Pardubice, the Czech Republic. They engaged with the main buyer of Foxconn Pardubice to remedy the situation. Central improvements were a minimum guaranteed income for temporary indirect workers and improved production planning that has allowed workers to better plan their shifts and decreased the need for sudden weekend shifts (EW, 2007).

More recently, Electronics Watch reported the largest settlement of migrant worker recruitment fees in a single company. In 2020, at Cal-Comp Electronics in Thailand, violations such as unlawful recruitment fees for Myanmar migrant workers and worker coercion to cover up the situation were found. After three years working with Cal-Comp Thailand and its major buyers, 10,570 workers received full compensation for excessive recruitment fees they had paid (EW, 2020b).

Developments like these are made possible through the leverage public buyers have as big buyers, their specification of social criteria as contractual obligations, and follow-up on reported violations in their supply chains using worker-driven monitoring methods. Establishing where the products public buyers procure are manufactured is central to worker-driven monitoring. Advances are visible with global brands providing detailed information on factory location beyond first-tier suppliers to Electronics Watch.

The bottom-up approach of corporate monitoring ensures a meaningful worker voice, thus making possible sustainable improvements for workers. Making trust-based relations with workers central, worker-driven monitoring increases understanding of sensitive issues such as 
sexual harassment and forced labor-these are the important problems that corporate-led auditing methodology often fails to uncover. Throughout the monitoring and improvement processes, workers are well informed of the progresses. This is an important feedback loop for local monitoring organizations to understand whether the announced corrective actions plans are implemented and how this affects workers.

To effectively work towards long-term improvements, the affiliates cannot be passive delegates. They should develop their collaborative capacity and utilize the expertise Electronics Watch and its monitoring partners provide to actively communicate with brands and manufacturers to improve working conditions. Fundamentally, this requires deeper organizational transformation and greater participation from each and every affiliated public buyer.

Putting workers' interest at the center, Electronics Watch and public buyers have advanced a more responsive and accountable structure of governance where workers can become strong stakeholders. Through this international framework for responsible public procurement, we envision support for what Chan, Selden and Pun (2020: 205) describe as 'a new round of global labor struggles.'

\section{Conclusion}

\section{Mark Selden and Jenny Chan}

Over the past four decades, China has risen from the global periphery to a middle-income economic and trade powerhouse and a major recipient and supplier of international investment (Hung and Selden, 2017). Hundreds of millions of 'new workers', the majority from the countryside, were drawn into manufacturing linked to global supply chains. In 2018 China's world share of merchandise exports reached $13 \%$, exceeding that of the United States (8\%) and Japan (4\%) combined (Lo, 2020: 862). The diversification and dynamism of the 'Chinese model', characterized by a hybrid economy of foreign, private and state capital, has simultaneously given rise to profound class and income disparities.

In a rising China, continued deep-rooted state discrimination against rural migrants, and consequent division between workers with urban and rural household registrations, is a source both of fragmentation among workers and discontent leading to labor actions. Dying for an iPhone narrates a despotic global labor regime and life and death struggles. Food and drink, sleeping, washing and other aspects of workers' daily lives are scheduled just like production lines. In desperation, a migrant worker identifies himself with the Foxconn suicide victims, writing in the first person, 'Leap, I use my life to seek human dignity' (Chan et al., 2020: 189). In this concluding section, we reflect on the prospects for workers to enhance their power in the face of entrenched power of states and the global electronics industry.

\section{State protections, labor rights and citizenship rights}

States bear responsibility to protect workers, including internal and international migrants, from discrimination, poverty and inequality. Activists have persistently pressured for citizenship rights, such as access to employment, housing, healthcare, childcare, education and other social 
benefits. The ability to mobilize national governments to regulate trade and labor policies is crucial to the success of social movements (Seidman, 2007). The large number of strikes and protests in recent decades has prompted the Beijing leadership to expand labor protections.

From 2016, the amended labor law limited subcontract workers from agencies to $10 \%$ of the workforce. Likewise, updated regulations on vocational school internships stipulated that the 10\% limit applies to student interns (Chan et al., 2020: 183-184). These measures are intended to improve employment stability for workers as well as to manage training programs for students. But local officials frequently circumvent legal requirements and collude with enterprises to enhance labor flexibility at the sacrifice of the interests of both employees and subcontract laborers.

We document the failure of the Chinese government to protect the labor and educational rights of 'student workers' to the detriment of the interests of the entire labor force. As Greg Distelhorst convincingly argues, when local governments use coerced student internships to reduce competitive pressures on employers to improve worker incomes and retain staff, they dampen economic growth and social development. Clearly, a stronger framework with a corresponding mechanism of enforcement for limiting flexible employment is essential.

\section{Worker empowerment through collaborative approaches}

We strive to expand labor rights to build economic and political development on a firmer social foundation. Democratic worker representation, collective bargaining, and effective dispute resolution are key elements (Anner, 2012; Appelbaum and Lichtenstein, 2016; Kuruvilla and Li, 2021). From a gender perspective, sexual harassment and various types of inequality in job assignment and performance assessment — which are often grossly neglected — need to be monitored and overcome (Chan et al., 2020: 123-125). Benjamin Selwyn applauds efforts by workers to safeguard their rights to decent work, including a living wage and a safe and healthy working environment.

Coordinated efforts are required to make systemic and industrywide improvements. Peter Pawlicki and Olga Martin-Ortega explain how Electronics Watch collaborates with public sector buyers and civil society organizations to secure industry support for fundamental labor rights. In contrast to anti-sweatshop campaigns dependent on dispersed consumers, socially responsible public procurement is premised on collaboration with brands and manufacturers to raise international human rights standards (EW and RBA, 2021). In fact, the two types of global campaigns could reinforce one another.

In the context of Chinese electronics, Dimitri Kessler shows that the government has not held employers accountable for workplace suicides despite consistent evidence that employers' infringements of workers' rights often provoke and heighten the risk of suicide. And for their part, suppliers and their buyers have denied responsibility to prevent more deaths, let alone improve workers' well-being. Looking beyond the Apple-Foxconn value chain, Joonkoo Lee emphasizes the enduring challenges to achieve worker rights in a globalized system of production based on a large pool of low wage labor and calls for economic and social upgrading.

\section{Towards new labor research}


In this final section, we suggest four new directions in action-oriented research beyond disciplinary boundaries. First, we need to look into the tiered employment system and its evolution. This means compiling long-term data documenting the changing ratio of subcontract workers to regular employees on a monthly and yearly basis, the wage and welfare differentials of worker subgroups (such as rural migrants and urban workers, male and female workers, as well as skilled and unskilled workers), and the pathways for informal workers to transition to formal ones with full benefits. The aggregation of information from a large number of electronics factories can reveal the centrality and current trends in flexible employment. At the firm level, researchers may analyze the ability of workers to present collective demands, including playing a role in corporate hiring, retention and promotion.

Second, we call for comprehensive investigations into the causes of work-related suicide in the electronics industry and comparison with findings for other industries in China and globally. If, as we believe, coercion and repression of worker voices are among the major factors contributing to depression and suicide, both workers (unions) and management should expand and strengthen employee voice mechanisms. Moving from conditions at the locus of production, researchers should simultaneously attend to the upstream supply chain structures, such as ordering and delivery requirements and the ways they shape wages, hours, and intensity of work. Our immediate objective is to mobilize corporate, union and government resources needed for deeper prevention efforts. A larger goal is to educate with a view to supporting the legal recognition of workplace suicides.

Third, we encourage studies of public procurement policies by countries and regions to identify facilitating and inhibiting factors for implementing ethical purchasing practices of computers and other electronic equipment in the public sector. These factors may include cultural sensitivity to supply-chain labor, gender and environmental issues as bases for a new procurement framework. Our vision is an expanded public sector role in protecting workers throughout the entire electronics supply chains. Public buyers use public funds and hold significant contracts for electronics products. As such, they have an opportunity to contribute to protect the rights and safety of workers by referencing contractual agreements and public procurement regulations.

Fourth, we welcome research on skills training and career advancement for interns and workers. With state subsidies, the use of industrial robots is growing in assembly, packaging and quality testing. While automation technologies can boost output and manufacturing productivity, tensions arise as labor intensive jobs are replaced and industrial relations are changed. Now is the time to introduce appropriate training through curriculum planning and school-business partnership to co-create a sustainable, post-pandemic future.

\section{Acknowledgements}

We gratefully acknowledge Nicki Lisa Cole, Monique Lempers, Sun Wook Chung, and Jeroen Merk for their intellectual support. Editor David Fasenfest offered very helpful advice.

\section{Funding}

The work described in this article is partially supported by funding from the Hong Kong Polytechnic University (P0000548) and the Research Grants Council of the Hong Kong Special Administrative Region, China (RGC25602517). 


\section{References}

Aitken HGJ (1985) Scientific Management in Action: Taylorism at Watertown Arsenal, 19081915. Princeton, NJ: Princeton University Press.

Anner M (2012) Corporate social responsibility and freedom of association rights: The precarious quest for legitimacy and control in global supply chains. Politics \& Society 40(4): 609-644.

Appelbaum R and Lichtenstein N (eds) (2016) Achieving Workers' Rights in the Global Economy. Ithaca, NY: Cornell University Press.

Apple (2011) Annual report for the fiscal year ended September 24, 2011. Available at: https://investor.apple.com/sec-filings/sec-filings-details/default.aspx?FilingId=8204587 [Accessed 31 March 2021].

Apple (2021) Supplier responsibility: 2020 progress report. Available at: https://www.apple.com/ca/supplierresponsibility/pdf/Apple SR 2020 Progress Report.pdf [Accessed 31 March 2021].

Barrientos S, Gereffi G and Rossi A (2011) Economic and social upgrading in global production networks: A new paradigm for a changing world. International Labour Review 150(3-4): $319-340$.

Bartley T (2007) Institutional emergence in an era of globalization: The rise of transnational private regulation of labor and environmental conditions. American Journal of Sociology 113(2): 297-351.

Bartley T (2018) Rules without Rights: Land, Labor, and Private Authority in the Global Economy. Oxford: Oxford University Press.

Beaumont P (2020) 'We squandered a decade': World losing fight against poverty, says UN academic. The Guardian, 7 July. Available at: https://www.theguardian.com/globaldevelopment/2020/jul/07/we-squandered-a-decade-world-losing-fight-against-poverty-saysun-academic [Accessed 31 March 2021].

Borrus MG, Ernst D and Haggard S (2000) International Production Networks in Asia: Rivalry or Riches? London: Routledge.

Boudreau L (2020) Multinational enforcement of labor law: experimental evidence from Bangladesh's apparel sector. Private Enterprise Development in Low-Income Countries (PEDL) Research Paper, Centre for Economic Policy Research. Available at: https://pedl.cepr.org/sites/default/files/WP\%205531\%20Boudreau\%20MultinationalEnforce mentOfLaborLaw.pdf [Accessed 31 March 2021].

Braverman H (1974) Labor and Monopoly Capital: The Degradation of Work in the Twentieth Century. New York: Monthly Review Press.

Case A and Deaton A (2020) Deaths of Despair and the Future of Capitalism. Princeton, NJ: Princeton University Press.

Chan A (2003) Racing to the bottom: International trade without a social clause. Third World Quarterly 24(6): 1011-1028.

Chan J, Selden M and Pun N (2020) Dying for an iPhone: Apple, Foxconn and the Lives of China's Workers. Chicago: Haymarket Books and London: Pluto Press.

Chen L, Li W, He J, et al. (2012) Mental health, duration of unemployment, and coping strategy: A cross-sectional study of unemployed migrant workers in Eastern China during the economic crisis. BMC Public Health 12(597): 1-12. 
Claeson BS (2019) Making rights effective in public procurement supply chains: Lessons from the electronics sector. In: Martin-Ortega O and Methven O'Brien C (eds) Public Procurement and Human Rights: Opportunities, Risks and Dilemmas for the State as Buyer. Cheltenham, UK: Edward Elgar Publishing, pp. 192-205.

Clean Clothes Campaign (2019) Fig leaf for fashion: How social auditing protects brands and fails workers. Available at: https://respect.international/wp-content/uploads/2020/01/FigLeaf-for-Fashion-How-Social-Auditing-Protects-Brands-and-Fails-Workers.pdf [Accessed 31 March 2021].

Distelhorst G (2020) Multinational corporations as labor regulators. In: Pohler D (ed) Reimagining the Governance of Work and Employment. Ithaca, NY: Cornell University Press, pp. 165-181.

Distelhorst G, Hainmueller J and Locke RM (2017) Does lean improve labor standards? Management and social performance in the Nike supply chain. Management Science 63(3): $707-728$.

Distelhorst G, Locke RM, Pal T, et al. (2015) Production goes global, compliance stays local: Private regulation in the global electronics industry. Regulation \& Governance 9(3): 224242.

Durkheim E (1897) Suicide: A Study in Sociology, trans. Spaulding JA and Simpson G. New York: The Free Press.

Elfström M (2021) Workers and Change in China: Resistance, Repression, Responsiveness. Cambridge: Cambridge University Press.

ERI and EW (Economic Rights Institute and Electronics Watch) (2018) The link between employment conditions and suicide: a study of the electronics sector in China. Available at: https://electronicswatch.org/the-link-between-employment-conditions-and-suicide-a-studyof-the-electronics-sector-in-china-november-2018 2549396.pdf [Accessed 31 March 2021].

EW (Electronics Watch) (2017) Compliance report: Foxconn in Pardubice, Czech Republic. Available at: https://electronicswatch.org/en/compliance-reports-foxconn-in-pardubiceczech-republic-june-2018 2541758.pdf [Accessed 31 March 2021].

EW (Electronics Watch) (2020a) When compliance is not enough: Why victims of forced labour should be partners in the remediation design. Available at: https://electronicswatch.org/when-compliance-is-not-enough-why-victims-of-forced-labourshould-be-partners-in-the-remediation-design 2572369.pdf [Accessed 31 March 2021].

EW (Electronics Watch) (2020b) Cal-Comp: A lesson in the importance of worker-driven monitoring to end forced labour in global supply chains. Available at: https://electronicswatch.org/cal-comp-a-lesson-in-the-importance-of-worker-drivenmonitoring-to-end-forced-labour-in-global-supply-chains-february-2020 2569307.pdf [Accessed 31 March 2021].

EW and RBA (Electronics Watch and Responsible Business Alliance) (2021) Terms of Engagement for the Responsible Business Alliance and Electronics Watch. Available at: https://electronicswatch.org/ew-rba-terms-of-engagement march-12 2587052.pdf [Accessed 31 March 2021].

Esbenshade J (2004) Monitoring Sweatshops: Workers, Consumers, and the Global Apparel Industry. Philadelphia, PA: Temple University Press.

Foxconn Technology Group (2020) 2019 corporate social responsibility report. Available at: https://www.foxconn.com/en-us/CSR [Accessed 31 March 2021]. 
Friedman E (2014) Insurgency Trap: Labor Politics in Postsocialist China. Ithaca, NY: Cornell University Press.

Fu D (2018) Mobilizing without the Masses: Control and Contention in China. Cambridge: Cambridge University Press.

Gallagher ME (2017) Authoritarian Legality in China: Law, Workers, and the State. Cambridge: Cambridge University Press.

Gereffi G (2018) Global Value Chains and Development: Redefining the Contours of 21st Century Capitalism. Cambridge: Cambridge University Press.

Gereffi G, Lim HC and Lee J (2021) Trade policies, firm strategies, and adaptive reconfigurations of global value chains. Journal of International Business Policy. Epub ahead of print 16 March. DOI: https://doi.org/10.1057/s42214-021-00102-z.

Howell J and Pringle T (2019) Shades of authoritarianism and state-labour relations in China. British Journal of Industrial Relations 57(2): 223-246.

Hua J (2018) The Foxconn suicides: Human vitality and capitalist consumption. Women's Studies in Communication 41(4): 320-323.

Hung HF and Selden M (2017) China's postsocialist transformation and global resurgence: Political economy and geopolitics. In: Fürst J, Pons S and Selden M (eds) The Cambridge History of Communism, Volume III, Endgames? Late Communism in Global Perspective, 1968 to the Present. Cambridge: Cambridge University Press, pp. 502-528.

ILO (International Labour Organization) (2016) Wages, productivity and labour share in China. Available at: https://www.ilo.org/wcmsp5/groups/public/---asia/---robangkok/documents/publication/wcms_475254.pdf [Accessed 31 March 2021].

Kan M (2014) Foxconn CEO blames past worker suicides on breakups, family disputes. PC World, 25 June. Available at: https://www.pcworld.com/article/2367900/foxconn-ceoblames-past-worker-suicides-on-breakups-family-disputes.html [Accessed $31 \mathrm{March} 2021$ ].

Kaplinsky R, Morris M and Readman J (2002) The globalization of product markets and immiserizing growth: Lessons from the South African furniture industry. World Development 30(7): 1159-1177.

Kim, H, Suh BS, Lee WC, et al. (2019) The association between long working hours and marital status change: Middle-aged and educated Korean in 2014-2015. Annals of Occupational and Environmental Medicine 31(1): 1-10.

Koo H (2001) Korean Workers: The Culture and Politics of Class Formation. Ithaca, NY: Cornell University Press.

Kraemer KL, Linden G and Dedrick J (2011) Capturing value in global networks: Apple's iPad and iPhone. Available at: http://economiadeservicos.com/wpcontent/uploads/2017/04/value ipad iphone.pdf [Accessed 31 March 2021].

Kuruvilla S and Li C (2021) Freedom of association and collective bargaining in global supply chains: A research agenda. Journal of Supply Chain Management. Epub ahead of print 19 January. DOI: https://doi.org/10.1111/jscm.12259.

LeBaron G and Lister J (2016) Ethical audits and the supply chains of global corporations. SPERI Global Political Economy Brief No. 1, Sheffield Political Economy Research Institute, The University of Sheffield. Available at: http://speri.dept.shef.ac.uk/wpcontent/uploads/2018/11/Global-Brief-1-Ethical-Audits-and-the-Supply-Chains-of-GlobalCorporations.pdf [Accessed 31 March 2021].

Lee CK (2019) China's precariats. Globalizations 16(2): 137-154. 
Lin L and Zhang J (2017) Impulsivity, mental disorder, and suicide in rural China. Archives of Suicide Research 21(1): 73-82.

Liu G (2014) Private employment agencies and labour dispatch in China. Sectoral Activities working paper No. 293, Geneva: International Labour Office. Available at: https://www.ilo.org/wcmsp5/groups/public/---ed dialogue/---sector/documents/publication/wcms 246921.pdf [Accessed 31 March 2021].

Liu M and Tsai KS (2020) Structural power, hegemony, and state capitalism: Limits to China's global economic power. Politics \& Society. Epub ahead of print 17 August. DOI: https://doi.org/10.1177/0032329220950234.

Lo D (2020) Towards a conception of the systemic impact of China on late development. Third World Quarterly 41(5): 860-880.

Locke RM (2013) The Promise and Limits of Private Power: Promoting Labor Standards in a Global Economy. New York: Cambridge University Press.

Locke RM and Samel H (2018) Beyond the workplace: 'Upstream' business practices and labor standards in the global electronics industry. Studies in Comparative International Development 53(1): 1-24.

Lollo N and O'Rourke D (2020) Factory benefits to paying workers more: The critical role of compensation systems in apparel manufacturing. PLoS ONE 15(2): 1-24.

Lüthje B and Butollo F (2017) Why the Foxconn model does not die: Production networks and labour relations in the IT industry in South China. Globalizations 14(2): 216-231.

Martin-Ortega O (2018) Public procurement as a tool for the protection and promotion of human rights: A study of collaboration, due diligence and leverage in the electronics industry. Business and Human Rights Journal 3(1): 75-95.

Martin-Ortega O, Outhwaite O and Rook W (2015) Buying power and human rights in the supply chain: Legal options for socially responsible public procurement of electronic goods. The International Journal of Human Rights 19(3): 341-368.

McKay SC (2006) Satanic Mills or Silicon Islands? The Politics of High-tech Production in the Philippines. Ithaca, NY: Cornell University Press.

MSI Integrity (2020) Not fit-for-purpose: The grand experiment of multi-stakeholder initiatives in corporate accountability, human rights and global governance. Available at: https://www.msi-integrity.org/wpcontent/uploads/2020/07/MSI Not Fit For Purpose FORWEBSITE.FINAL .pdf [Accessed 31 March 2021].

Nelson V, Martin-Ortega O and Flint M (2020) Making human rights due diligence work for small farmers and workers in global supply chains. University of Greenwich Report Commissioned by the Fair Trade Advocacy Office (FTAO) and Brot für die Welt. Available at: https://fairtrade-advocacy.org/wp-content/uploads/2020/06/UoG-HRDD-Full-Report60pp-FINAL-SECURED.pdf [Accessed 31 March 2021].

Outhwaite $\mathrm{O}$ and Martin-Ortega $\mathrm{O}$ (2019) Worker-driven monitoring - Redefining supply chain monitoring to improve labour rights in global supply chains. Competition \& Change 23(4): 378-396.

Phelps NA, Miao JT, Li Z and Lin S (2021) From socialist subject to capitalist object: Industry enclave life past and present in Wuhan. International Journal of Urban and Regional Research 45(1): 99-115.

Phillips DP (1974) The influence of suggestion on suicide: Substantive and theoretical implications of the Werther effect. American Sociological Review 39(3): 340-354. 
Phillips MR, Liu H and Zhang Y (1999) Suicide and social change in China. Culture, Medicine and Psychiatry 23(1): 25-50.

Pun N, Andrijasevic R and Sacchetto D (2020) Transgressing North-South divide: Foxconn production regimes in China and the Czech Republic. Critical Sociology 46(2): 307-322.

RBA (Responsible Business Alliance) (2018) Responsible Business Alliance Initiative launched to advance worker well-being. Available at: http:/www.responsiblebusiness.org/news/initiative-launched-to-advance-worker-wellbeing/ [Accessed 31 March 2021].

Rozelle S, Xia Y, Friesen D, et al. (2020) Moving beyond Lewis: Employment and wage trends in China's high- and low-skilled industries and the emergence of an era of polarization. Comparative Economic Studies 62: 555-589.

SACOM (Students and Scholars Against Corporate Misbehavior) (2011) The truth of the Apple iPad. [YouTube]. Available at: https://youtu.be/V3YFGixp9Jw [Accessed 31 March 2021].

Seidman GW (2007) Beyond the Boycott: Labor Rights, Human Rights, and Transnational Activism. New York: Russell Sage Foundation.

Selwyn B (2017) The Struggle for Development. Cambridge: Polity Press.

Selwyn B (2019) Poverty chains and global capitalism. Competition \& Change 23(1): 71-97.

Selwyn B and Leyden D (2021) Oligopoly-driven development: The World Bank's Trading for Development in the Age of Global Value Chains in perspective. Competition \& Change. Epub ahead of print 23 March. DOI: https://doi.org/10.1177/1024529421995351.

Starrs S (2013) American economic power hasn't declined-It globalized! Summoning the data and taking globalization seriously. International Studies Quarterly 57(4): 817-830.

Täht K and Mills M (2016) Out of Time: The Consequences of Non-standard Employment Schedules for Family Cohesion. Dordrecht, The Netherlands: Springer.

Taylor FW (1903) Shop management. ASME Transactions 24: 1337-1480.

Taylor FW (1911) The Principles of Scientific Management. London: Routledge.

Toffel MW, Short JL and Ouellet M (2015) Codes in context: How states, markets, and civil society shape adherence to global labor standards. Regulation \& Governance 9(3): 205223.

Waters S (2020) Suicide Voices: Labour Trauma in France. Liverpool: Liverpool University Press.

World Bank (2020) World Development Report 2020: Trading for development in the age of global value chains. Washington, DC. Available at:

https://www.worldbank.org/en/publication/wdr2020 [Accessed 31 March 2021].

Yang Y and Gallagher M (2017) Moving in and moving up? Labor conditions and China's changing development model. Public Administration and Development 37(3): 160-175.

Yang Y and McMorrow R (2021) Chinese courier sets fire to himself in protest over unpaid Alibaba wages. Financial Times, 12 January. Available at: https://www.ft.com/content/d6189ee8-9aea-41dd-a412-b8daba9cacf2 [Accessed 31 March 2021].

\section{ORCID iD}

Greg Distelhorst https://orcid.org/0000-0002-3623-7953

Dimitri Kessler https://orcid.org/0000-0002-8949-9391

Joonkoo Lee https://orcid.org/0000-0001-5772-397X

Olga Martin-Ortega https://orcid.org/0000-0002-1779-0120 
Mark Selden https://orcid.org/0000-0002-0829-9807
Benjamin Selwyn https://orcid.org/0000-0002-0279-8656

For Correspondence: Jenny Chan (陳慧玲) Room HJ433, Department of Applied Social Sciences, The Hong Kong Polytechnic University, Hong Kong jenny.wl.chan@polyu.edu.hk 


\section{Figure 1: Publicly referenced suicides}

\section{ECONOMIC RIGHTS INSTITUTE}

BUILDING BRIDGES TO BETTER WORK

\section{NUMBER OF PUBLICLY REFERENCED SUICIDES}

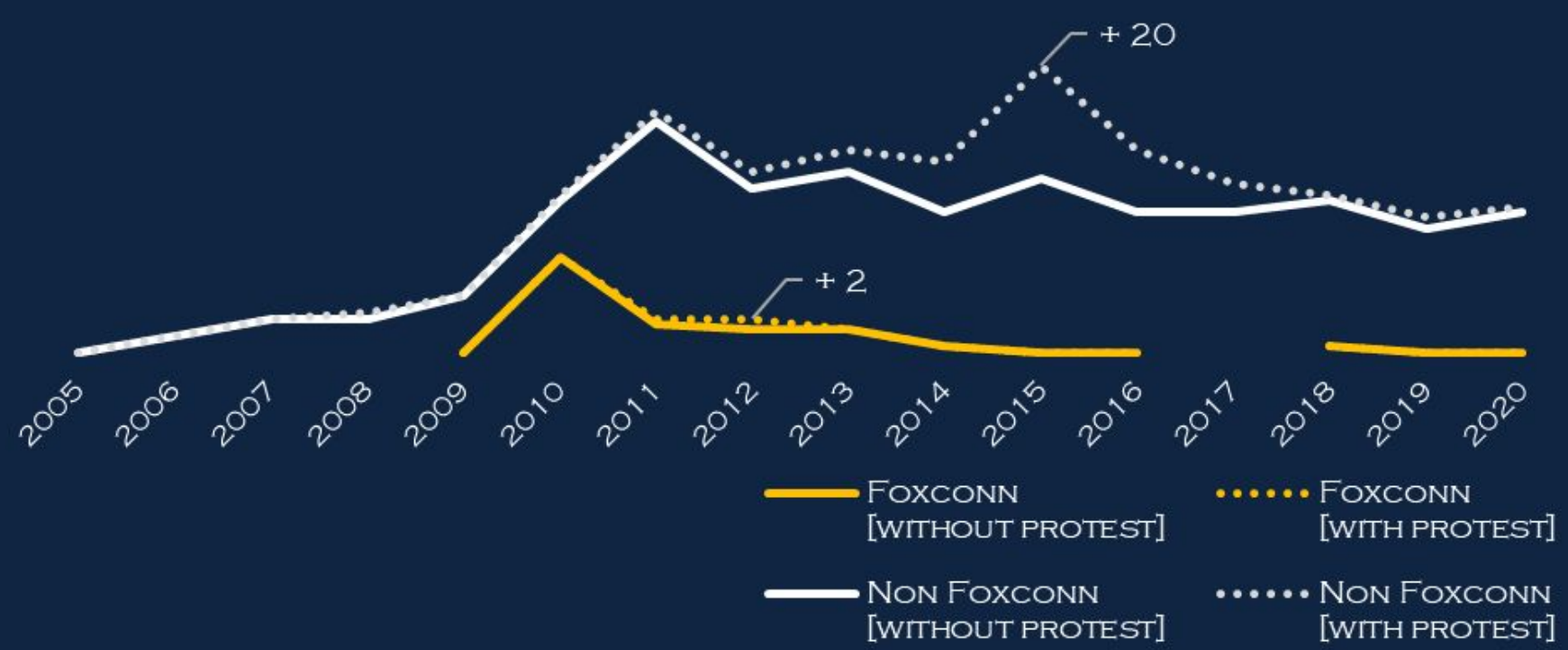

Sources including but not limited to:

- Online blogs [e.g., bbs.tianya.cn, blog.sina.com.cn, tieba.baidu.com, weibo.com, wickedonna.blogspot.com, zhidao.baidu.com]

- News outlets from Hong Kong [e.g., hk.apple.nextmedia.com], mainland China [e.g., baoliao.oeeee.com, boxun.com, chinanews.com, ne ws.sina.com.cn, news.sohu.com] and elsewhere [e.g., epochtimes.com, rfa.org] 
Table 1: Publicly referenced suicides

\begin{tabular}{|c|c|c|c|}
\hline & & Foxconn & \\
\hline Yr & $\begin{array}{c}\text { \# of } \\
\text { suicides }\end{array}$ & $\begin{array}{c}\text { \# of } \\
\text { sum of }\end{array}$ & $\begin{array}{c}\text { suicide } \\
\text { suicide } \\
\text { incidents }\end{array}$ \\
\hline 2003 & 0 & 0 & 0 \\
\hline 2004 & 0 & 0 & 0 \\
\hline 2005 & 0 & 0 & 0 \\
\hline 2006 & 0 & 0 & 0 \\
\hline 2007 & 1 & 0 & 1 \\
\hline 2008 & 0 & 0 & 0 \\
\hline 2009 & 1 & 0 & 1 \\
\hline 2010 & 18 & 0 & 18 \\
\hline 2011 & 6 & 1 & 7 \\
\hline 2012 & 5 & 2 & 7 \\
\hline 2013 & 5 & 0 & 2 \\
\hline 2014 & 2 & 0 & 1 \\
\hline 2015 & 1 & 0 & 1 \\
\hline 2016 & 1 & 0 & 0 \\
\hline 2017 & 0 & 0 & 2 \\
\hline 2018 & 2 & 0 & 1 \\
\hline 2019 & 1 & 0 & 1 \\
\hline 2020 & 1 & 0 & 47 \\
\hline & 44 & 3 & \\
\hline
\end{tabular}

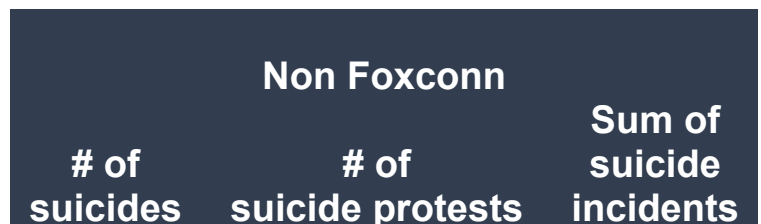

suicides suicide protests incidents

\begin{tabular}{|c|c|c|}
\hline 1 & 0 & 1 \\
\hline 0 & 0 & 1 \\
\hline 1 & 0 & 4 \\
\hline 4 & 0 & 7 \\
\hline 7 & 0 & 8 \\
\hline 7 & 1 & 11 \\
\hline 11 & 0 & 29 \\
\hline 28 & 1 & 44 \\
\hline 42 & 2 & 33 \\
\hline 30 & 3 & 37 \\
\hline 33 & 4 & 35 \\
\hline 26 & 9 & 52 \\
\hline 32 & 20 & 37 \\
\hline 26 & 11 & 31 \\
\hline 26 & 5 & 29 \\
\hline 28 & 1 & 25 \\
\hline 23 & 2 & 27 \\
\hline 26 & 1 & 411 \\
\hline 351 & 0 & \\
\hline
\end{tabular}

Foxconn \&

non-Foxconn

Sum of

suicide

incidents

\begin{tabular}{|c|}
\hline 1 \\
\hline 1 \\
\hline 4 \\
8 \\
\hline 8 \\
12 \\
\hline 47 \\
\hline 51 \\
40 \\
\hline 42 \\
\hline 37 \\
53 \\
\hline 38 \\
\hline 31 \\
\hline 31 \\
\hline 26 \\
\hline 28 \\
\hline 458 \\
\hline
\end{tabular}

